\title{
MANAGEMENT OF STUDENT CHARACTER BASED ON EMOTIONAL INTELLIGENCE AT AMIK NURMAL LUWUK BANGGAI
}

\author{
Marwan M. Londol, Haris Panal, Hamzah B. Uno and Arfan Arsyad \\ Educational Science Study Program, Postgraduate Program, \\ Gorontalo State University, Indonesia
}

\begin{abstract}
This study aims to analyze student character management based on emotional intelligence at AMIK Nurmal Luwuk Banggai. The research method used in this study is a qualitative research approach. Sources of data in this study were the director, manager, student majoring in computers, alumni of Amik Nurmal Luwuk, the community, parents, lecturers and graduate users (company) Amik Nurmal, Banggai Regency, Central Sulawesi Province, who were considered to be able to provide information according to the needs of researchers. The results showed that action with vision, strong in facing change, and able to work in teams. Student character management based on emotional intelligence at Amik Nurmal Luwuk Banggai is done by familiarizing yourself with positive things. This management is implemented through the education curriculum for Religion, Pancasila and civic education(PPKn), Ethics and Professionals, Interpersonal Skills and Work Motivation, Academic Orientation (ORMIK), KKMK (entrepreneurial self-employment lectures), skills training, Field practice (PKL) activities and field observations, organizational and social activities. -The program of activities is believed to be able to manage student character based on emotional intelligence, Amik Nurmal Luwuk Banggai, because in participating in the activities as mentioned, will teach students how to work in groups, independently, understand each other, share, care between each other, inform or inform each other.
\end{abstract}

Key words: Character Management, Students, Emotional intelligence

Cite this Article: Marwan M. Londol, Haris Panal, Hamzah B. Uno and Arfan Arsyad, Management of Student Character Based on Emotional Intelligence at AMIK Nurmal Luwuk Banggai, International Journal of Management, 11(12), 2020, pp 1825-1832.

http://iaeme.com/Home/issue/IJM?Volume=11\&Issue=12 


\section{INTRODUCTION}

Character is very important and basic. Character is the life necessity that distinguishes humans from animals. People with strong character and both individually and socially are those who have good morals, morals, and character. Given that all is very important, it must be started from the world of education (Bass \&Steidlmeier, 1999; Smith, 2011).

In planning student character management, the main stakeholders are curriculum and lecturers because curriculum and lecturers are the main targets of managing student character itself, by involving all educational stakeholders in planning student character management, so the management of student character is expected to be in accordance with global needs and demands. The curriculum will determine which direction students will take after studying, while the lecturers know best about the problems they face in learning in the world of campus (Campbell \& Li, 2008).

The learning system related to character education for AMIK students NurmalLuwukBanggai (such as professional ethics, PKN and Religion), in practice, emphasizes the left brain aspect (memorization, or just "knowing"). Seeing the character building of AMIK Student NurmalLuwukBanggai must be carried out systematically and continuously which involves the aspects of "knowledge, feeling, loving, and acting". Character building can be likened to the formation of a person to become a body builder who requires continuous "moral muscle training" in order to be strong and strong.

Thus, to form student character that leads to positive actions, the involvement of all components of education is needed, in this case the involvement of parents, family, community, lecturers and other related parties in managing the character of AmikNurmalLuwukBanggai students better. Especially emotional intelligence. Daniel Goleman (2000) states that emotional intelligence is: a person's ability to recognize their personal emotions so that they know their strengths and weaknesses; Someone's ability to manage their emotions; A person's ability to motivate and provide encouragement to advance on himself; A person's ability to recognize other people's emotions and personalities; A person's ability to build relationships with other parties well (Ford, 1992; Huy, 1999; McQueen, 2004). If we are able to understand and implement the five main areas of emotional intelligence, then any business journey or career we take will have a better chance of running smoothly.

The obstacle to AmikNurmalLuwukBanggai's education in producing quality graduates is that there are still many education systems that have a mindset that has not been directed in carrying out the learning process. Higher education only emphasizes logic (mathematics) and language skills. These types of intellectual intelligence are known as multi-intelligence introduced by Gardner (1983) which have not been maximally applied. The multiple intelligences studied in this study are based on intellectual intelligence (IQ), emotional intelligence (EQ), and spiritual intelligence (SQ) (Tischler et al., 2002; Animasahun, 2010).

This condition certainly deserves to be studied in-depth, especially to reveal the implementation of higher education policies at AMIK NurmalLuwukBanggai in order to improve life skills (vocational) and its implications for the welfare of the community, especially its alumni. The purpose of this study was to analyze the character management of students based on emotional intelligence at AMIK NurmalLuwukBanggai.

\section{METHODS}

This research approach is qualitative research. A qualitative research approach that places more emphasis on disclosing meanings and processes with a natural background as a direct source of data. A qualitative approach is used because of the match between the 
characteristics and characteristics that are suitable, including the main instrument is the human/researcher himself, because the researcher is directly in the field in the data collection process. Based on this technique, the data sources in this study were the director, manager, student majoring in computer, Amik Nurmal Luwuk alumni, community, parents, lecturers and graduate users (company) Amik Nurmal, Banggai Regency, Central Sulawesi Province, which were considered to be able to provide information according to the needs of researchers. The three stages of activities carried out in qualitative research data analysis in this study are data reduction, data presentation and conclusion drawing.

\section{RESULTS AND DISCUSSION}

\subsection{Character Management of Amik Nurmal Luwuk Banggai Students Based on Emotional Intelligence}

The findings of the aspect of understanding self-emotion and the emotions of others show that the lecturer acts as a mediator when discussions take place or argue uncontrollably, through positive habituation, being role models for students, students trying to understand their own strengths and weaknesses, mingling with friends By not discriminating between ethnicities, religions and beliefs, many learn from the experiences of successful people through real examples in everyday life. Then campus programs such as religious education courses, citizenship education, ethics and professional courses, academic orientation activities (ORMIK), KKMK activities (independent entrepreneurship work courses), skills training, street vendors and other activities, are forms of character management. emotional intelligence-based students on the aspects of understanding the emotions themselves and the emotions of others.

The findings also show that activities that support the management of student character based on emotional intelligence in terms of students having full aspects of self-confidence, including doing assignments without cheating on friends' work, trying to collect assignments on time, following lecturer directions, habituating themselves in thinking positively towards self-ability, not complaining about the situation at hand, having the courage to ask or answer questions, provide rebuttals or input during discussion activities, lecturers provide understanding to students to think positively and organize the future and follow as best as possible campus programs in terms of self-development, such as student skills training, street vendors activities, entrepreneurial self-employment courses and student organization activities.

The findings also show that activities that support the management of student character based on emotional intelligence in terms of students having a strong will to succeed, among others, motivate students to aspire and strive to achieve them, tell the success experiences of a person or community leader who has been successful, provide encouragement as well as strengthening their aspirations in order to strive to achieve them, focus on the desired goals, trying to complete assignments given by the lecturer in a timely manner, trying to stay enthusiastic, not giving up when experiencing difficulties, being selective in socializing in class or in the community, keeping up study time on campus and at home, develop yourself through positive activities and pray for every action taken.

The findings show that activities that support the management of student character based on emotional intelligence in terms of students aligning actions with ideals, including providing understanding for discipline in lecture activities, instilling self-confidence, the campus has designed a vision and mission to encourage students to act in completed his studies. Then apply the lecture method that involves student activeness, motivating students to immediately complete studies, finding solutions for students with academic problems and involving students in their self-development activities, instilling ideals to be achieved and 
with the encouragement of parents, and remembering the sacrifices of parents, study hard, be on time in lectures and engage in organizational activities and learn from the experiences of successful people.

The findings also show that activities that support the management of student character based on emotional intelligence in terms of students being strong in facing change, including fostering student self-confidence and improving student skills for strengthening basic skills by programming training and training activities, instilling student mental so that by training Student skills, remind students to study diligently, provide motivation and a true picture of the world of work, strengthen the student's basic knowledge that refers to the campus vision and mission and strive for self-flexibility in order to face change.

Other findings show that activities that support the management of student character based on emotional intelligence in terms of being able to work together as a team, can be done by providing direction to students and motivating students to work in groups and giving assignments in groups, providing instructions in completing group assignments, each Group members have their respective duties and responsibilities, listen to the direction of the lecturer or group leader in terms of the division of tasks and responsibilities of each group member.

The findings in the field show that most of AmikNurmalLuwukBanggai's students have emotional intelligence-based characters that are needed in the field of work by companies in Banggai Regency. Thus, AmikNurmalLuwukBanggai alumni who work at companies in LuwukBanggai Regency are mostly successful in the world of work and are able to survive, however, some other students have not matched the demands of work.

Based on the description above, a concept map for managing student character based on emotional intelligence is made as follows:

Character management is an effort made deliberately to help students understand themselves to have a noble personality. Etymologically, character management can be interpreted as something that is innate in nature that affects behavior, character, character, or temperament. In terminology, the character can be interpreted as psychological, moral or character traits that are characteristic of certain students.

Management of student character based on emotional intelligence. among others: so that students understand the emotions of themselves and others, be full of confidence; a strong will to succeed, align action with vision, strong against change, and able to work in teams.

Management of student character in terms of emotional intelligence is related to planning, organizing, directing or implementing, providing motivation and monitoring learning in the lecture process on the emotional aspects of students in a positive direction.

In planning student character management based on emotional intelligence, the main stakeholders are curriculum and lecturers because curriculum and lecturers are the main targets of managing student character itself, by involving all educational stakeholders in planning student character management, so the management of student character is expected to be in accordance with the needs and demands. global. The curriculum will determine the direction students will take after taking their education, while the lecturers know best about the problems they face in learning on campus. The combination of education actors and the involvement of education planning stakeholders that are formulated will be relevant to the needs of students. 
Character Management of Amik Nurmal Luwuk Banggai Students Based on Emotional Intelligence
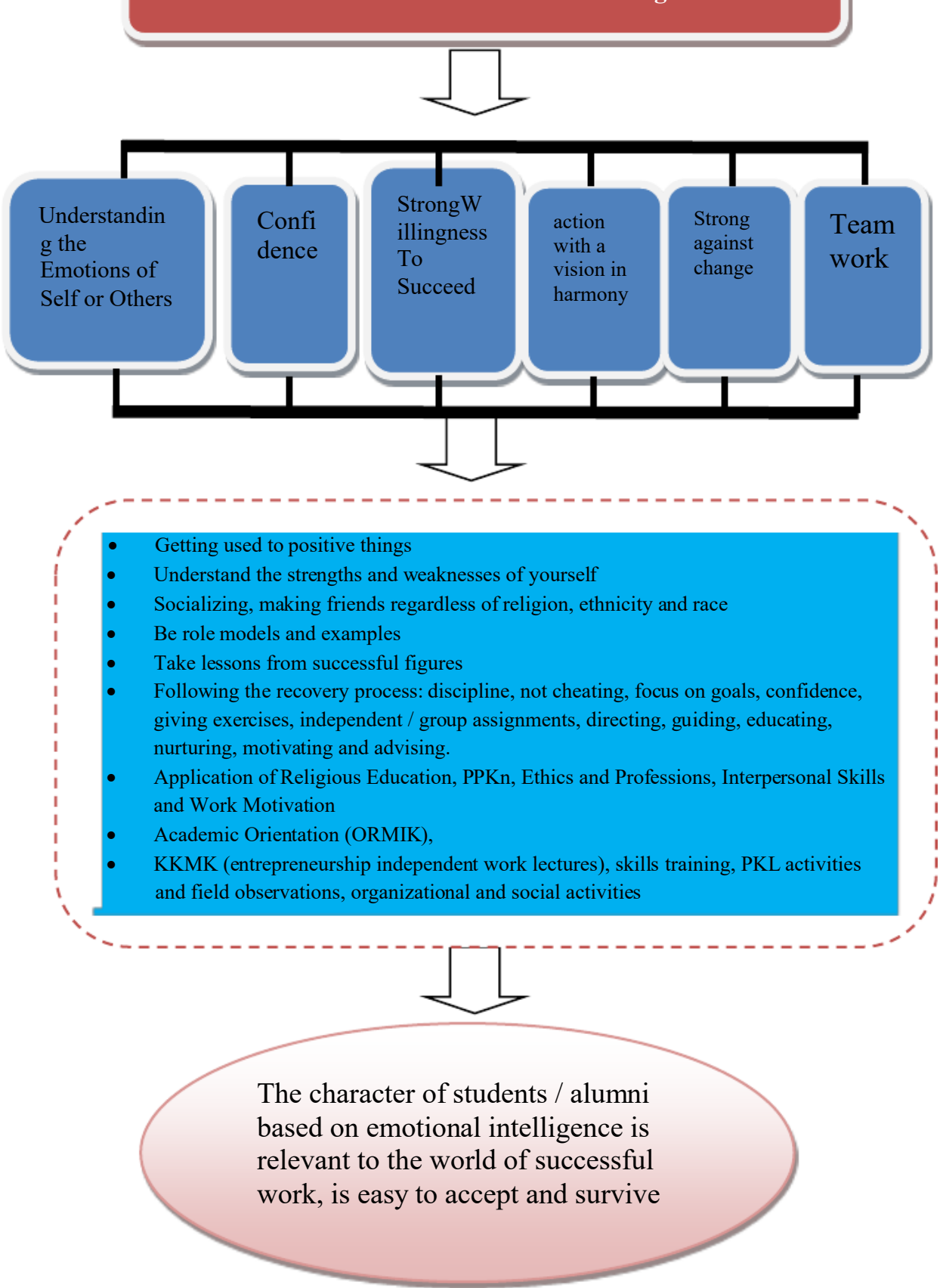

Figure 1 Student Character Management Based on Emotional Intelligence Amik Nurmal Luwuk Banggai

Organizing student character based on emotional intelligence is one of the strategies in terms of formulating formal structures, processes and a series of learning activities in the division of tasks planned to be completed by students, determining good task relationships between them, and maintaining the appropriate learning environment and facilities.

Implementation in terms of directing students related to character management based on emotional intelligence, which is more appropriate is lecturers who guide courses because lecturers already know their students, are familiar with student skills and abilities, understand 
student capacity and attention, know what students can produce, and lecturers of course, have observed student behavior.

Furthermore, giving motivation is a process and a series of activities that must be carried out by a lecturer, parents, community, colleagues in providing inspiration, enthusiasm, and excitement to be active in work and encouragement to students to be able to carry out an activity as expected. With the provision of motivation for students, students will feel the care of educators, parents, society, peers for themselves, students will feel a closer emotional relationship with educators, parents, society and their peers.

Then, supervision or control which is the last part of the management function is carried out to find out: a) all activities in developing emotional intelligence-based character that have been carried out according to the previous plan; b) knowing all obstacles, losses, abuse of power and authority, deviations and waste in the implementation of planning to manage character based on emotional intelligence; c) avoid abuse of power and authority, deviations, failures, losses, and waste in managing the character based on emotional intelligence.

Mulyasa (2011) suggests that to manage student character in a positive direction based on emotional intelligence, habituation is necessary. For example, activities that are carried out spontaneously, namely habituation such as forming greeting behavior, disposing of trash in its place, cultivating oneself to behave in a queue (Manoe, 2020).

This opinion is similar to that expressed by Gunawan (2012) managing student character based on emotion through various activities, including routine activities, always maintaining body hygiene, class pickets, congregational prayer, praying before studying and after, saying greetings when meeting educators, or colleagues; spontaneous activities, for example collecting donations when there is a disaster that occurs in the community or friends who experience disaster, exemplary, giving examples of praiseworthy deeds by lecturers, or others to students and even fellow students, for example, the value of discipline, cleanliness and tidiness, compassion, politeness, caring, honesty and hard work; conditioning, the creation of conditions that support the implementation of character management, such as clean toilets, trash cans, green pages with trees, posters of wisdom in public places or strategic campus locations.

Based on this description, to achieve better emotional intelligence-based student character management, it is necessary to have activities that support or improve student character. These activities can be in the form of habituation to routine activities, spontaneous activities (sudden), modeling, conditioning as previously described.

The strategy for implementing character education is developed through the knowing, acting, and habit stages. In addition, character management based on students' emotional intelligence is to apply moral loving in their lives. Moral loving is the strengthening of the emotional aspects of students to become human characters (Gunawan, 2012). These reinforcements are related to the forms of attitude that students must feel, namely awareness of identity, self-confidence, sensitivity to the suffering of others, love of truth, self-control, generosity, learning to love, getting used to being kind (Renaldi, 2020). Educators can apply this concept by providing examples to students.

Furthermore, those who play a role in managing student character based on emotional intelligence, one of which is the campus world. The role of campuses as moral educators is becoming increasingly vital at a time when millions of students, in particular, receive little moral teaching from their parents and when the influence of places that are central to values such as places of worship is also absent in their lives (Lickona, 2013). Character management is not limited to knowledge alone, someone who has good knowledge is not necessarily able to act according to his knowledge if he is not trained (habituation) to do this good. 
Activities carried out in managing the character of Amik Nurmal Luwuk Banggai students are based on emotional intelligence, that is, since students enrolled as Amik Nurmal Luwuk Banggai students are accustoming themselves to positive things, understanding one's strengths and weaknesses, socializing, making friends without distinction of religion, ethnicity and race, being role models and examples, taking lessons from successful figures, following the recovery process: discipline, not cheating, focus on goals, confidence, giving training, independent / group assignments, directing, guiding, educating, fostering, motivating and to advise.

Ormic activities, the application of Religious education, PPKn, Ethics and Professionals, Interpersonal Skills and Work Motivation are programs that students must acquire from the start. In the implementation of this activity, the material taught is an introduction to the campus, moral values that must be built by students, characteristics that must be prioritized in conducting lectures, cooperation, relationships between people and others. The next activity is campus extracurricular activities such as competitions, competitions and forming or joining Islamic organizations, religious studies, and other organizations. The next activity, is to attend seminars, street vendors, courses, independent work lectures, social activities and other relevant activities.

These activity programs are believed to be able to manage student character based on student emotional intelligence, Amik Nurmal Luwuk Banggai. Because in participating in the activities as mentioned above, it will teach students how to work in groups, independently, understand each other, share, care for each other, inform or inform one another. Thus, if accustomed to participating in these activities, it will have an impact on the character of the students themselves and will achieve educational goals.

\section{CONCLUSION}

Characteristics of emotional intelligence-based students at Amik Nurmal Luwuk Banggai include: understanding the emotions of themselves and others, full of self-confidence; strong will to succeed, align action with vision, strong against change, and able to work in teams. Student character management based on emotional intelligence at Amik Nurmal Luwuk Banggai is carried out by familiarizing oneself with positive things, understanding one's strengths and weaknesses, associating, making friends without distinguishing religion, ethnicity and race, being role models and examples, taking lessons from successful figures, follow the recovery process: discipline, not cheating, focus on goals, self-confidence, giving training, independent / group assignments, directing, guiding, educating, fostering, motivating and advising. This management is implemented through the Religion education curriculum, Pancasila and Citizenship Education (PPKn), Ethics and Professionals, Interpersonal Skills and Work Motivation, Academic Orientation (ORMIK), KKMK (entrepreneurship independent work-study), skills training, fieldwork practical activities (PKL) and field observations, organizational and social activities.

\section{REFERENCES}

[1] Animasahun, R. A. (2010). Intelligent quotient, emotional intelligence and spiritual intelligence as correlates of prison adjustment among inmates in Nigeria prisons. Journal of Social sciences, 22(2), 121-128.

[2] Bass, B. M., \& Steidlmeier, P. (1999). Ethics, character, and authentic transformational leadership behavior. The leadership quarterly, 10(2), 181-217.

[3] Campbell, J., \& Li, M. (2008). Asian students' voices: An empirical study of Asian students' learning experiences at a New Zealand university. Journal of Studies in International education, 12(4), 375-396. 
[4] Ford, M. E. (1992). Motivating humans: Goals, emotions, and personal agency beliefs. Sage Publications.

[5] Galgo, J. (2020). Endeavours towards Academic Success: An Investigation of Underprivileged Student's Life Experience. Middle Eastern Journal of Research in Education and Social Sciences, 1(2), 94-106. https://doi.org/10.47631/mejress.v1i2.46

[6] Gardner, D. P. (1983). A nation at risk: The imperative for educational reform: A report to the nation and the Secretary of Education, United States Department of Education. The Commission.

[7] Goleman, D. (2000). Leadership that gets results. Harvard business review, 78(2), 4-17.

[8] Gunawan, H. (2012). Pendidikan karakter. Bandung: alfabeta, 2.

[9] Huy, Q. N. (1999). Emotional capability, emotional intelligence, and radical change. Academy of Management review, 24(2), 325-345.

[10] Lickona, T. (2013). Pendidikan karakter: Panduan lengkapmendidiksiswamenjadipintar dan baik. Bandung: Nusa Media.

[11] Manoe, L. (2020). Modified Instructional Teaching Method. Journal La Edusci, 1(1), 7-11.

[12] McQueen, A. C. (2004). Emotional intelligence in nursing work. Journal of advanced nursing, 47(1), 101-108.

[13] Mulyasa, E. (2011). Manajemenpendidikankarakter. Jakarta: BumiAksara, 165-189.

[14] Renaldi, S. (2020). Using Instagram to Improve Students' Ability and Interest in Writing Descriptive Paragraph. Journal La Edusci, 1(1), 12-24.

[15] Smith, C. (2011). What is a person?: Rethinking humanity, social life, and the moral good from the person up. University of Chicago Press.

[16] Tischler, L., Biberman, J., \& McKeage, R. (2002). Linking emotional intelligence, spirituality and workplace performance. Journal of managerial psychology. 